\title{
Metals Phytotoxicity Assessment and Phyto Maximum Allowable Concentration
}

\author{
NO Ryzhenko* \\ Department of Ecology, National University of Kyiv-Mohyla Academy, Ukraine
}

Received: 非 September 09, 2018; Published: 酸 September 14, 2018

*Corresponding author: NO Ryzhenko, Department of Ecology, Faculty of Natural Sciences, National University of Kyiv-Mohyla Academy, 2 Skovoroda Street, Ukraine

\begin{abstract}
In this paper, the influence of metals ( $\mathrm{Cd}, \mathrm{Pb}, \mathrm{Cu}, \mathrm{Co}, \mathrm{Ni}, \mathrm{Zn}$ ) on plants of spring barley (Hordeum vulgare L.) was investigated in polluted sod podzolic sandy loam on layered glacial sands and calcareous deep chernozem on loamy loess soils. We propose to highlight the metals' phytotoxicity with help of the Phyto Maximum Allowable Concentration. The Phyto Maximum Allowable Concentration is a permissible level of metals for plants in polluted soil and represents the safe degree for plants in contaminated ecosystem. The Phyto Maximum Allowable Concentration gives the possibility to estimate and to forecast the danger of metals for plants as a biological object that plays a very important role in the life of ecosystem. This approach may be applied for another metals phytotoxicity assessment for other plants.
\end{abstract}

Keywords: Metals; Plants; Phyto Maximum Allowable Concentration; Assessment, Pollution; Phytotoxicity

\section{Introduction}

Metals are significant environmental pollutants, and their toxicity is a problem of increasing significance for ecological, evolutionary, nutritional and environmental reasons Nagajyoti [1]; Bieby Voijant Tangahu [2]; Mamatha [3]; Metals, such as cadmium, copper, lead, nickel, cobalt and mercury are major environmental pollutants, particularly in areas with high anthropogenic pressure. Metal accumulation in soils and plants is of concern in agricultural production due to the adverse effects on food safety and marketability, crop growth due to phytotoxicity, and environmental health of soil organisms. The influence of plants and their metabolic activities affects the geological and biological redistribution of heavy metals through pollution of the air, water and soil Nagajyoti [1]; Gyuricza [4] Anthropogenic metals contamination of ecosystems as a result of the application of industrial, transport, agrarian and other technologies causes a damage of the functioning of plants as an important component in ecosystem Bradl[5]; Alloway [6]; Kabata-Pendias [7] Often plants are the main accumulator of metals in polluted ecosystem. In the same time, plants play an important role in ecosystem as biomass producers and as biodiversity creators Rombke [8]; Kabata-Pendias [7]; Sardar [9]. Usually phytotoxicity is considered as a harmful influence of metal on plant growth and development Kabata Pendias [7]; Nagajyoti [1]; Satpathy[10]; Gill [11] . However, the setting of a safe level of toxicant for the plant is also very important, because it can help to prevent and to control the negative effects of metals in the ecosystem. Today a methodology that would determine the safe concentration of metals directly for plants in the soil is absent. After all, the existing standards for the content of metals in environmental objects are sanitary-hygienic and focused just on human health Lewis [12]; Smirnov [13]; Warne [14]. Determination of the metals safe level in the soil for plants can help to objectively assess state of the ecosystem and prevent the metals dangerous influence on plant Ryzhenko [15]. The Phyto Maximum Allowable Concentration (PMAC) was suggested as safe level of metal in the soil for plants.

\section{Materials and Methods}

Spring barley (Hordeum vulgare L.) was selected as a model plant. Spring barley (Hordeum vulgare L.) is one of the important cereals crop in Ukraine. Mean standard deviations, variance, and minimum, maximum, standard errors were calculated from at least three replicates. The experimental results were interpreted using standard statistical methods. The soils of experimental pots were: sod podzolic sandy loam on layered glacial sands (sod podzolic) 
and calcareous deep chernozem on loamy loess (chernozem). Sod podzolic soil has the following physic chemical characteristics: pHsalt 5,5; organic matter by Turin $0,87 \%$, CEC $6,3 \mathrm{mg}$ eqv $/ 100 \mathrm{~g}$. Chernozem soil has the following: $\mathrm{pH}_{\text {salt }} 6,2$, organic matter by Turin 2,89\%, CEC 27,1mg eqv/100g. Background concentration of metals in soil (1 M HCl, $\mathrm{mg} \mathrm{kg}^{-1)}$ was: $\mathrm{Cd}-0,1 ; \mathrm{Pb}-0.3 ; \mathrm{Cu}=0.92 ; \mathrm{Zn}-2.4$; $\mathrm{Ni}$ - 1.1; Co-1,5 (sod podzolic); $\mathrm{Cd}=0.11 ; \mathrm{Pb}-0.32 ; \mathrm{Cu}-2.6 ; \mathrm{Zn}-5.3$; $\mathrm{Ni}$ - 2.3; Co - 2,5 (chernozem). Studied trace elements: $\mathrm{Cd}, \mathrm{Pb}, \mathrm{Zn}$, $\mathrm{Cu}, \mathrm{Co}$, Ni were applied separately in amount equal to the following concentration in the soils (Table 1).

Table 1: Scheme of Experiment.

\begin{tabular}{|c|c|}
\hline \multicolumn{2}{|c|}{ Control (no HM application) } \\
\hline $\mathrm{Cu}^{2+}:$ & $\mathrm{Zn}^{2+}:$ \\
\hline $100 \mathrm{mg} \mathrm{kg}^{-1}$ of the soils, & $600 \mathrm{mg} \mathrm{kg}^{-1}$ of the soils, \\
\hline $150 \mathrm{mg} \mathrm{kg}^{-1}$ of the soils, & $900 \mathrm{mg} \mathrm{kg}^{-1}$ of the soils, \\
\hline $200 \mathrm{mg} \mathrm{kg}-1$ of the soils, & $1200 \mathrm{mg} \mathrm{kg}^{-1}$ of the soils), \\
\hline $300 \mathrm{mg} \mathrm{kg}^{-1}$ of the soils & $1500 \mathrm{mg} \mathrm{kg}^{-1}$ of the soils \\
\hline $\mathrm{Co}^{2+}:$ & $\mathrm{Ni}^{2+}:$ \\
\hline $60 \mathrm{mg} \mathrm{kg}^{-1}$ of the soils & $70 \mathrm{mg} \mathrm{kg}^{-1}$ of the soils \\
\hline $300 \mathrm{mg} \mathrm{kg}^{-1}$ of the soils & $210 \mathrm{mg} \mathrm{kg}^{-1}$ of the soils, \\
\hline $480 \mathrm{mg} \mathrm{kg}^{-1}$ of the soils + & $350 \mathrm{mg} \mathrm{kg}^{-1}$ of the soils, \\
\hline $540 \mathrm{mg} \mathrm{kg}^{-1}$ of the soils & $420 \mathrm{mg} \mathrm{kg}^{-1}$ of the soils, \\
\hline $600 \mathrm{mg} \mathrm{kg}^{-1}$ of the soils & $700 \mathrm{mg} \mathrm{kg}^{-1}$ of the soils \\
\hline $\mathrm{Cd}^{2+}:$ & $\mathrm{Pb}^{2+}:$ \\
\hline $15 \mathrm{mg} \mathrm{kg}^{-1}$ of the soils, & $150 \mathrm{mg} \mathrm{kg}^{-1}$ of the soils, \\
\hline $30 \mathrm{mg} \mathrm{kg}-1$ of the soils, & $300 \mathrm{mg} \mathrm{kg}^{-1}$ of the soils, \\
\hline $60 \mathrm{mg} \mathrm{kg}^{-1}$ of the soils, & $450 \mathrm{mg} \mathrm{kg}^{-1}$ of the soils, \\
\hline $90 \mathrm{mg} \mathrm{kg}^{-1}$ of the soils, & $900 \mathrm{mg} \mathrm{kg}^{-1}$ of the soils, \\
\hline $150 \mathrm{mg} \mathrm{kg}^{-1}$ of the soils, & $1200 \mathrm{mg} \mathrm{kg}^{-1}$ of the soils, \\
\hline $300 \mathrm{mg} \mathrm{kg}^{-1}$ of the soils & $1500 \mathrm{mg} \mathrm{kg}^{-1}$ of the soils \\
\hline
\end{tabular}

That amount corresponds with adopted in Ukraine Maximum Allowed Concentration (MAC) in soil (Medvedev [16]. The following metals salts: $\mathrm{Pb}\left(\mathrm{NO}_{3}\right)_{2}, \mathrm{ZnSO}_{4}$. $\mathrm{H}_{2} \mathrm{O}, \mathrm{CuSO}_{4} \cdot 7 \mathrm{H}_{2} \mathrm{O}, \mathrm{CdSO}_{4}, \mathrm{NiSO}_{4} \cdot 6 \mathrm{H}_{2} \mathrm{O}$, $\mathrm{CoSO}_{4} \cdot 7 \mathrm{H}_{2} \mathrm{O}$ were used for the trace elements application. The investigation was conducted in green house conditions. Plants grew in plastic Mitcherlikh's pots. Soil preparation, pots filling, and trials were carried out in accordance with standard methodic Dospekhov [17]; Medvedev [16]. The metals were added to soil during soil preparation before filling the pots. Then, spring barley germinated seeds were planted into the pots and, in the stage of 3 leaves, the recommended population was established. The studied elements were extracted by $1 \mathrm{M} \mathrm{HCl}$ from the soils. The method of HM determination was thin layer chromatography (TLC). Method widely was used in our previous investigation and officially recognized in Ukraine Kavetsky [18].

\section{Results and Discussion}

In this study, the algorithm of calculation of PMAC was proposed similar to the existing approach of calculation of Maximum
Allowable Toxic Concentration (MATC) (equation 1) Rand [19]. In the toxicology practice, the scheme to substance toxicity assessment using the LOEC and NOEC is quite effective and widely used Smirnov [12]; Warne [13] Environment Canada. Guidance document on statistical methods for Environmental Toxicity Tests [20]; Globally Harmonized System of Classification and Labeling of Chemicals (GHS), fourth revised version, [21]. These indicators are used also for calculate the Maximum Allowable Toxic Concentration (MATC) on behalf of assessing the toxicity of substances in the aquatic environment. MATC is calculated by the formula Rand [19]:

$$
\text { MATC }=\sqrt{((N O E C) *(L O E C))},(1)
$$

where NOEC is No Observed Effect Concentration;

LOEC is Lowest Observed Effect Concentration.

We propose to determine the Phyto Maximum Allowable Concentration by the formula:

$$
\mathrm{PMAC}=\sqrt{\left(\mathrm{C}_{-}\right. \text {contr }} *\left(\mathrm{PhLD} \rrbracket_{-5}\right)(2)
$$

where $\mathrm{C}_{\text {contr }}$ - background concentration (on the control variant of experiment-without additional metal input);

The $\mathrm{PhLD}_{5}$ is phytotoxic dose $5 \%\left(\mathrm{PhLD}_{5}\right)$ caused reduction of $5 \%$ of initial weight (height, length of root etc.).

In our opinion, $5 \%$ reduction of initial weight (height, length of root etc.) is the minimal effect, which is similar to the LOEC shows the preliminary changes in the productivity of the plant population. Moreover, the level of significance of deviations, which are considered sufficient for ecological and biological research at the level of $5 \%$ ( $p<0.05)$ was chosen. The algorithm of obtaining the $\mathrm{PhLD}_{5}$ was represented in previous papers Ryzhenko [22]. Table 2 shows the values of $\mathrm{PhLD}_{5}$ and PMAC for all investigated metals, as well as the background concentration in soil ( 0 -20 centimeters). PMAC was obtained with the help of equation 2. The PMAC for $\mathrm{Cd}$ in sod podzolic soil was calculated in this way:

Table 2: $\mathrm{PhLD}_{5}$, PMAC, and background concentration in soil (0-20 centimeters, $\left.1 \mathrm{~N} \mathrm{HCl}, \mathrm{mg} \mathrm{kg}^{-1}\right)$.

\begin{tabular}{|c|c|c|c|}
\hline Metal & PhLD5 & $\begin{array}{c}\text { Ccontr (Background concentration } \\
\text { in soil, 0-20cm) }\end{array}$ & PMAC \\
\hline \multicolumn{5}{|c|}{ Sod podzolic (1M HCl, $\mathbf{~ m g ~ k g - ~} \mathbf{~}^{\mathbf{}}$ ) } \\
\hline $\mathrm{Cd}$ & 14.72 & $0.10 \pm 0.02$ & 1.21 \\
\hline $\mathrm{Pb}$ & 186.64 & $0.30 \pm 0.05$ & 7.48 \\
\hline $\mathrm{Zn}$ & 394.46 & $2.40 \pm 0.30$ & 30.77 \\
\hline $\mathrm{Cu}$ & 62.91 & $0.92 \pm 0.10$ & 7.60 \\
\hline $\mathrm{Co}$ & 57.94 & $1.50 \pm 0.15$ & 9.77 \\
\hline $\mathrm{Ni}$ & 50.12 & $1.10 \pm 0.10$ & 7.40 \\
\hline & & Chernozem (1 M HCl, $\left.\mathbf{~ m g ~ k g}^{-1}\right)$ & 1.46 \\
\hline $\mathrm{Cd}$ & 19.25 & $0.11 \pm 0.02$ & 9.20 \\
\hline $\mathrm{Pb}$ & 264.24 & $0.32 \pm 0.05$ & \\
\hline
\end{tabular}




\begin{tabular}{|c|c|c|c|}
\hline $\mathrm{Zn}$ & 380.19 & $5.30 \pm 0.50$ & 44.90 \\
\hline $\mathrm{Cu}$ & 65.61 & $2.60 \pm 0.20$ & 13.10 \\
\hline $\mathrm{Co}$ & 74.13 & $2.50 \pm 0.20$ & 13.61 \\
\hline $\mathrm{Ni}$ & 69.98 & $2.30 \pm 0.30$ & 12.69 \\
\hline
\end{tabular}

4. Veronika Gyuricza, Ferenc Fodor, Zoltán Szigeti (2010) Phytotoxic Effects of Heavy Metal Contaminated Soil Reveal Limitations of Extract-Based Ecotoxicological Tests. Water, Air, \& Soil Pollution 210(1-4): 113-122.

5. Bradl H (2005) Heavy Metals in the Environment: Origin, Interaction and Remediation. Neubrucke Academic Press 6: 282.

(PMAC)_Cd $=\sqrt{ }\left(0.1^{*} 14.72\right)=1.21 \mathrm{mg} \mathrm{kg}^{-1}(3)$

The PMAC for $\mathrm{Ni}, \mathrm{Pb}, \mathrm{Cu}, \mathrm{Co}, \mathrm{Zn}$ in two soils were calculated similarly.

The lowest value of the PMAC had Cd, the highest value of the PMAC had $\mathrm{Zn}$ in two studied soils. The chornozem soil ad higher values of the PMAC than Sod podzolic soil. It could be explained by higher content of organic matter, granulometric composition of soil and other properties of chornozem soil. According to the value of PMAC, the metals can be ranked in the following descending order: $\mathrm{Zn}>\mathrm{Co}>\mathrm{Cu}>\mathrm{Ni}>\mathrm{Pb}>\mathrm{Cd}$. The PMAC could be used as an environmental standard that regulate the safe level of pollutants in the soil for plant [23-25].

\section{Conclusion}

As a result of this investigation, it was proposed to use the Phyto Maximum Allowable Concentration as a permissible level for plants in soil in the polluted ecosystem. The algorithm of calculation of Phyto Maximum Allowable Concentration based on the approach of the existing calculation of Maximum Allowable Toxic Concentration (MATC). The Phyto Maximum Allowable Concentrations were obtained for Hordeum vulgare L. for all researched metals in two soils (mg kg-1;1 N HCl): Cd-1.21; Cu - 7.60; Co-9.77; Zn - 30.77; $\mathrm{Ni}-7.40 ; \mathrm{Pb}-7.48$ (sod podzolic sandy loam on layered glacial sands), and Cd - 1.46; Cu - 13.10; Co-13.61; Zn- 44.90; Ni - 12.69; $\mathrm{Pb}-9,20$ calcareous deep chernozem on loamy loess). The Phyto Maximum Allowable Concentration gives the possibility to set the permissible level of metal in soil for plant as a biological organism, but not from the point of view of hygienic regulation. The using of concept of Phyto Maximum Allowable Concentration may be suitable for receiving a permissible level of metals in different soils for other plants in polluted ecosystems. Phyto Maximum Allowable Concentration gives the possibility to estimate the danger of metals directly for plants as a biological object that playing a very important role in the life of ecosystem.

\section{References}

1. PC Nagajyoti, KD Lee, TVM Sreekanth (2010) Heavy metals, occurrence and toxicity for plants: a review. Environ Chem 8(3): 199-216.

2. Bieby Voijant Tangahu, Siti Rozaimah Sheikh Abdullah, Hassan Basri Mushrifah Idris, Nurina Anuar (2011) A Review on Heavy Metals (As, $\mathrm{Pb}$, and $\mathrm{Hg}$ ) Uptake by Plants through Phytoremediation. International Journal of Chemical Engineering 2011: 31.

3. Mamatha P, Salamma S, Swamy AVN, B Ravi Prasad Rao (2014) Quantitative and risk analysis of heavy metals in selected leafy vegetables. Der Pharma Chemica, № 6(3): 179-185.

6. Alloway BJ (2010) Heavy metals in soils. Trace elements and Metalloids in Soils and their Bioavailability, ( $3^{\text {rd }}$ edn.), Springer, USA p. 235.

7. Kabata Pendias Alina, Mukherjee Arun B (2007) Trace Elements from Soil to Human. Berlin Heidelber Springer-Verlag, USA, p. 550.

8. Rombke J, Moltmann J F (1996) Applied Ecotoxicology. Boca Raton: Lewis Publishers p. 234

9. Kamran Sardar, Shafaqat Ali, Samra Hameed (2013) Heavy Metals Contamination and what are the Impacts on Living Organisms. Greener Journal of Environmental Management and Public Safety 2(4): 172-179.

10. Deepmala Satpathy, Vikram M Reddy, Soumya Prakash Dhal (2014) Risk Assessment of Heavy Metals Contamination in Paddy Soil, Plants, and Grains (Oryza sativa L.) at the East Coast of India. BioMed Research International p. 11.

11. Mukti Gill (2014) Heavy metal stress in plants: a review. International Journal of Advanced Research 2(6): 1043-1055.

12. Lewis RA (1998) Lewis' Dictionary of Toxicology. USA, pp. 1136.

13. Smirnov VG (2002) Estimated methods for hazard assessment and hygienic evaluation of harmful substances in environments. Maymulov VG Nechiporenko S V St Petersburg, Foliant, p. 130.

14. Michael St J Warne, and Rick van Dam (2008) NOEC and LOEC Data Should no Longer be Generated or Used? Australasian journal of ecotoxicology 14(1): 1-5.

15. Ryzhenko N, Kavetsky S, Kavetsky V (2017) Cd, Zn, Cu, Pb, Co, Ni Phitotoxicity Assessment.Polish Journal of Soil Science 2: 197-215.

16.VV Medvedev, TM Laktionova, SA Bal'uk, NM Blokhina, VO Bililypsky (1998) Method of monitoring of lands which are in the crisis state, Kharkiv, ON Sokolovsky' Institute of soil science p. 88.

17. Dospekhov BA (1985) Methodology of field experiment. Moscow: Agropromizdat pp. 313-316.

18. Kavetsky VN, Makarenko NA, Buogis AM, Kavetsky SV (2001) Thin Layer Chromatography Methods of the $\mathrm{Hg}, \mathrm{Zn}, \mathrm{Co}, \mathrm{Cd}, \mathrm{Cu}$, Ni determination in soil, plant and water, № 50-97. Methodic of determination pesticides residues in food, forage and environment, Kyiv, p. 18-23.

19. Rand G (1994) Fundamentals of Aquatic Toxicology. Boca Ration, CRC Press, USA, p. 943.

20. Environment Canada. Guidance document on statistical methods for Environmental Toxicity Tests. (2005): p. 113

21. Globally Harmonized System of Classification and Labelling of Chemicals (GHS), fourth revised vertion, UN NY and Geneva, 2011: 568.

22. Ryzhenko NO (2017) Principles of phytotoxicological normalization of metals. Bulletin of the Kremenchug National University named after Mikhail Ostrogradsky 4(105): 96-102.

23. Ryzhenko NO, Kavetsky VM (2017) Probit analysis for Cd, Pb, Cu, Zn phytotoxicity assessment. Biotechnologia Acta 10(2): 67-74.

24. Ryzhenko NO, Kavetsky SV, Kavetsky VM (2017) Cd, Zn, Cu, Pb, Co, Ni Phytotoxicity Assessment as Function of Its Substance Polarity Shift. International Journal of Bioorganic Chemistry 2: 163-173.

25. Gorodniy MM (2008) Agrochemistry Kyiv, Ariste p. 523. 


\section{(c) (i) This work is licensed under Creative}

To Submit Your Article Click Here: Submit Article

DOI: $10.32474 /$ AOICS.2018.03.000170

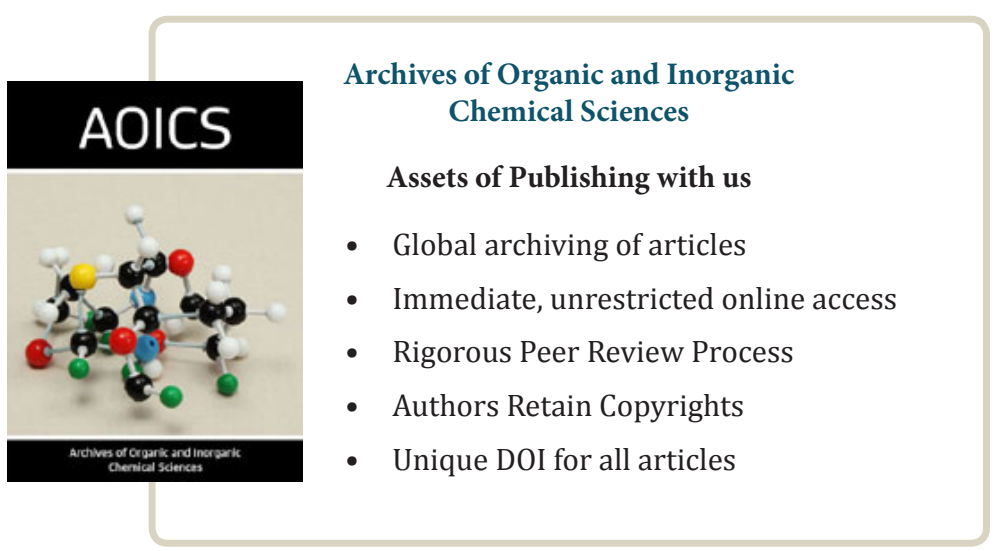

